\title{
Septoria yaprak leke hastalığı etmeni Zymoseptoria tritici (Desm. Quaedvlieg \& Crous)'ye ait izolatların farklı sıcaklıklardaki fizyolojik ve biyokimyasal özelliklerin belirlenmesi
}

\section{Determination of physiological and biochemical characteristics of isolates of septoria leaf blotch disease agent [Zymoseptoria tritici(Desm. Quaedvlieg \&Crous)] at different temperatures}

\author{
Nevzat KILINÇ ${ }^{1}$ iD, Murat DikiLiTAŞ ${ }^{2}$, Mukaddes KAYIM ${ }^{3}$ iD, Gülsüm ÜNAL ${ }^{4}$ iD
}

\author{
${ }^{1}$ Harran Üniversitesi, Ziraat Fakültesi, Bitki Koruma Bölümü, Ş.Urfa, Türkiye \\ ${ }^{2}$ Harran Üniversitesi, Ziraat Fakültesi, Bitki Koruma Bölümü, Ş.Urfa, Türkiye \\ ${ }^{3}$ Çukurova ÜniversitesiZiraat Fakültesi, Bitki Koruma Bölümü, Adana, Türkiye \\ ${ }^{4}$ Biyolojik Mücadele Araştırma Enstitüsü Müdürlüğü, Adana,Türkiye
}

${ }^{1}$ https://orcid.org/0000-0002-5747-5467; ${ }^{2}$ https://orcid.org/0000-0002-7399-4750;

${ }^{3}$ https://orcid.org/0000-0003-0309-0390; ${ }^{3}$ https://orcid.org/0000-0003-1190-3435

To cite this article:

Kılınç, N., Dikilitaş, M., Kayım, M. \& Ünal, G. (2021). Septoriayaprak leke hastalığı etmeni Zymoseptoria tritici(Desm. Quaedvlieg \&Crous)'ye ait izolatların farklı sıcaklıklardaki fizyolojik ve biyokimyasal özelliklerin belirlenmesi. Harran Tarım ve Gıda Bilimleri Dergisi, 25(4):469-479.

DOI: $10.29050 /$ harranziraat.897692

${ }^{*}$ Address for Correspondence: Nevzat KILINÇ

e-mail:

nvzt1298@gmail.com

\section{Received Date:}

16.03.2021

Accepted Date:

10.11.2021

(C) Copyright 2018 by Harran University Faculty of Agriculture. Available on-line at $\underline{\text { www.dergipark.gov.tr/harranziraat }}$

\section{öz}

Bu çalışma ileseptoria yaprak leke hastalığı etmeni Zymoseptoria tritici (Desm. Quaedvlieg \& Crous)'ye ait 4 izolatın farklı sıcaklık koşullarında (4-, 15-, 25-, 30-, 35ㄷ) fizyolojik (birim alandaki spor yoğunluğu, miselyal gelişim ve birim hacimdeki spor sayısı) ve biyokimyasal (protein, prolin, proteaz, melanin ve malonadialdehit) değişimleri incelenmiştir. Sıcaklık değerleri optimum $\left(25^{\circ} \mathrm{C}\right)$ değerden uzaklaştıkça patojenin fizyolojik ve biyokimyasal değerlerinde değişimler tespit edilmiştir. Birim alandaki spor yoğunluğu, ortalama büyüme çapı ve birim hacimdeki spor sayısında azalma olmuştur $(P \leq 0.05)$. Yüksek sıcaklıkta $\left(30-, 35^{\circ} \mathrm{C}\right)$ patojene ait protein miktarı azalmış, prolin, proteaz, melanin ve malonadialdehit (MDA) değerlerinde ise artış görülmüştür. Buna bağlı olarak fungus izolatları arasında gelişme oluştuğu saptanmıştır. Patojenin CU100StA4 nolu izolatı birim alandaki spor yoğunluğu, ortalama büyüme çapı, birim hacimdeki spor sayısı ve ürettiği proteaz miktarı itibari ile diğer izolatlardan pozitif olarak ayrışmıştır. Patojenin CU107StH110 nolu izolatının prolin, melanin ve malonadialdehit değerleri, diğer izolatlardan daha yüksek çıkmıştır. Yüksek sıcaklıkta (30-, $35^{\circ} \mathrm{C}$ ) proteaz enziminin üretilmesi ile uygun nem koşullarında fungusun virülensliğinin devam edebileceği gözlemlenmiştir. Fungusun proteaz enzim üretimi ile misel uzunluğu, protein ve prolin miktarları arasında pozitif bir ilişki olduğu belirlenmiştir.

Anahtar Kelimeler:Zymoseptoria tritici, Sıcaklık, Proteaz, Melanin, Malonadialdehit (MDA)

\section{ABSTRACT}

In this study, 4 isolates belonging to septoria leaf spot disease [Zymoseptoria tritici (Desm. Quaedvlieg \& Crous)] fungus and physiological (spore density per unit area) under different temperature conditions (4-, 15-, 25-, 30-, $35^{\circ} \mathrm{C}$ ) micellar growth and the number of spores per unit volume) and biochemical (protein, proline, protease, melanin and malonadialdehyde) changes were investigated. Spore density per unit area, average growth diameter and number of spores per unit volume decreased. Proline, protease, melanin and malonadialdehyde (MDA) values increased, while protein content of the pathogen decreased at high temperature (30-, $35^{\circ} \mathrm{C}$ ).Accordingly, it has been determined that there are differences in growth among the fungus isolates. The isolate numbered CU100StA4 of the pathogen was found to be higher 
than the other isolates in terms of spore density per unit area, average growth, diameter, number of spores per unit volume and the amount of protease produced. Proline, melanin and malonadialdehyde values of the isolate of the pathogen no. CU107StH110 were higher than the other isolates. It was observed that the presence of protease enzyme at high temperature $\left(30-, 35^{\circ} \mathrm{C}\right)$ and the virulence of the fungus could continue under suitable humidity conditions. It has been evaluated that there is a positive relationship between fungus protease enzyme production and micelle length, protein and proline values.

Key Words:Zymoseptoria tritici, Temperature, Protease, Melanin, Malondialdehyde (MDA)

\section{Giriş}

Buğdaylarda ürün kayıplarına neden olan septoria yaprak lekesi etmeninin (Zymoseptoria tritici) Afrika, Avrupa, Yakın Doğu, Asya, Avustralya ve Orta Amerika'da yaygın olduğu ve zaman zaman epidemi yaptığı bildirilmektedir (Goodwin ve ark., 2011). Z. tritici, buğday verim oranını \% 30 ila 50 azaltmakta, bu nedenle, küresel gıda güvenliği için bir tehdit olarak görülmektedir (Sidhu ve ark., 2015). Z. tritici'nin neden olduğu hastalığın Türkiye'de yaygın olduğu, Bremer ve ark. (1948), İren (1962) tarafından açıklanmıştır. Ülkemizin bütün bölgelerinde yaygın olduğu, uygun koşullarda, duyarlı çeşitlerde önemli kayıplar yapabilecek potansiyele sahip olduğu bildirilmiştir (Bora ve Karaca1970; Eğerci ve ark., 2020). Son yıllarda ülkemiz ve dünyada, yabancı kökenli buğday çeşitlerinin üretimi ile hastalık önemini daha da arttırmış kışlık buğdaylarda \%40'lara varan düzeylerde ürün kayıplarına neden olmuştur(Zhan ve ark., 2016).

$\mathrm{Bu}$ hastalık ile mücadelede birçok koruyucu fungisit önerilmesine karşın, pratikte ekonomik değildir. Bu nedenle kültürel önlemlerin yanı sıra dayanıklı çeşitlerinde yetiştirilmesi gerekmektedir (Torriani ve ark., 2009). Hastalık etmeni, aşırı gübreleme yapılan ve geniş yaprak oluşturan çeşitlerin yetiştirildiği yerlerde önemli ürün kayıplarına neden olmaktadır. Ana konukçusu buğday olmakla beraber arpa ve çayır bitkilerinde de görülmekte, anız, tohum, kendigelen buğday ve buğdaygiller bu fungal etmenin inokulum kaynaklarını oluşturmaktadır (Kurt, 2016).

Guo ve Verreet (2008), Z. tritici'nin izolatları üzerine ortam, ışık ve $\mathrm{pH}$ 'nın etkilerini in vitro koşullarda test etmişler, test edilen izolatların konidi üretiminde farklı karakterler sergilediğini, malt-maya özütü ortamından $1.82 \times 10^{9}$ konidi plaka $^{-1}$ üretildiğini ve karanlık koşullarda konidi oluşumun önemli ölçüde azaldığını bildirmişlerdir. Konidinin çimlenme ve çim tüpü büyümesinin ise $30^{\circ} \mathrm{C}^{\prime}$ de azaldığını belirlemişlerdir. Saidi ve ark. (2012), katı ortam (YMDA, maya özü, malt özü, dextros, agar) ve sıvı ortamlarda (YMB, maya özü, malt özü, glukoz, 1 litre saf su)Z. tritici'nin oluşturduğu spor miktarını verimlilik açısından değerlendirmişler, inokule edilmiş kültür ortamlarını 18 ve $20^{\circ} \mathrm{C}^{\prime}$ de $12^{\prime}$ şer saat karanlık/ışık ortamında 4-6 gün bulundurulduktan sonra sıvı ortamın 2 kat daha fazla spor ürettiğini rapor etmişlerdir. Bu durum fungus etmeninin uygun nem ve sıcaklık durumunda çok daha fazla gelişebileceğini ortaya koymuştur. Zhan ve ark. (2016), ise koloni ve miselyal gelişimin virülenslik ile uyumlu olduğunu aralarında pozitif bir korelasyon olduğunu ispat etmişlerdir. Mustafa (2020), Z. tritici patojeninin Türkiye'de eşeyli olarak üreme ve yağmur sıçramasıyla dağılan aseksüel sporlarla yayılımın yanı sıra askosporlarla da hava yoluyla yayıldığı hipotezini doğrulamaktadır. Eşeyli genetik rekombinasyon, Z. tritici'nin daha virülentpatotiplerini ortaya çıkarıcı potansiyeline sahip olduğunu bildirmiştir.

\section{Materyal ve Metod}

Adana, Kahramanmaraş, Hatay ve Mersin illerinden elde edilen Zymoseptoria tritici patojenine ait izolatlar, Çukurova Üniversitesi Ziraat Fakültesi Bitki Koruma Bölümü öğretim üyesi Prof. Dr. Mukaddes KAYIM ve Zir. Yük. Müh. Gülsüm ÜNAL'ın kültür koleksiyonlarından temin edilmiştir. Patojen izolatlarının tanısı mikroskobik ve moleküler analiz yöntemleri kullanılarak Ünal ve ark., (2017) tarafından yapılmıştır. PDA Petri 
ortamında geliştirilen izolatlar izole edildikleri illere göre, Adana: CU10StA4, K.Maraş: CU112StK239, Hatay: CU107StH110 ve Mersin: CU102StM34 olarak adlandırılmıştır. İzolatlar Petri kaplarında inokule edildikten sonra sırası ile A4, K239, H110 ve M34 olarak kısaltılmıştır. İzolatlar 4 tekerrür olacak şekilde farklı sıcaklıklarda (4-, 15-, $25-, 30$ ve $35^{\circ} \mathrm{C}$ ) tesadüf blokları deneme desenine göre inkübatörde inkübasyona bırakılmışlardır.

\section{Fungal sporulasyon}

Farklı sıcaklıklarda inkubasyona bırakılan fungus izolatlarında spor sayımı için, 10-, 20 ve 30. günlerde fungus kolonilerinden birer adet fungal disk (5 mm çapında) alınarak (3 tekerrür) tüplere konmuş ve $1 \mathrm{ml}$ su içinde sporlar ayrıştırıldıktan sonra tüpler vibratörde çalkalanarak sporların homojen bir şekilde suda dağılması sağlanmıştır. Elde edilen spor süspansiyonundan $10 \mu l^{\prime}$ lik bir hacim alınarak heamocytometreüzerinde ışık mikroskobu (SOIF B203, 10x40 büyütme) altında fungal sporlar sayılarak spor yoğunluğu birim alanda $\left(\mathrm{mm}^{2}\right)$ spor $\mathrm{ml}^{-1}$ olarak ifade edilmiştir.

\section{Fungaletmenin protein içeriğinin belirlenmesi}

Çözünebilir protein ölçümü için Petri ortamında gelişmeye bırakılan fungal kültürlerden Petri kaplarına dökülen $10 \mathrm{ml}$ steril su ile miseller yüzeyden kazınarak yaklaşık $0.1 \mathrm{~g}$ ağırlığında misel elde edilmiş, bu kütle fosfat buffer çözeltisinde (pH 7.0) havan ve havaneli ile homojenize edilerek, $10000 \mathrm{~g}$ de 10 dakika süre ile $4^{\circ} \mathrm{C}^{\prime} \mathrm{de}$ santrifüj edilmiştir (Dikilitaş ve ark., 2010). Elde edilen supernatant'tan Bradford (1976)'a göre protein okuması yapılmıştır. Bu metoda göre, 100 mg Coomassie Brilliant Blue G-250, 50 ml 95\%'lik etanol içinde çözündükten sonra solusyon $100 \mathrm{ml}$ 85\% lik w/v fosforik asit ile $\left(\mathrm{H}_{3} \mathrm{PO}_{4}\right)$ karıştırılıp, saf su ile 1 litreye tamamlanmıştır. Daha sonra 10$100 \mu \mathrm{g}$ arasında protein içeren örnekler $(100 \mu \mathrm{l}), 5$ $\mathrm{ml}$ hacminde Coomassie Brilliant Blue reagent ile karıştırılarak 10 dakika ile 1 saat arasında değişen süre içinde ölçülmüştür. Protein ölçümünde Bovine Serum Albumin (BSA) Fraction V standart protein olarak kullanılmış ve $10-100 \mu \mathrm{g}$ arasında değişen protein konsantrasyonları (stok solusyon,
$1 \mathrm{mg} \mathrm{ml}^{-1}$ ) $595 \mathrm{~nm}^{\prime}$ de ölçülerek elde edilen linear grafiğe göre örneklerin protein değerleri belirlenmiştir. Örnek okumaları spektrofotometrede (Shimadzu: UV-1800) gerçekleştirilip, sonuçlar mg protein $\mathrm{mg}^{-1}$ misel ağırlık olarak ifade edilmiştir.

\section{Proteazaktivitesi}

Proteaz enzim ölçümü için hücre dışı protease aktivitesi azocasein tabanlı amino asitlerin ve küçük peptitlerin fungal kültürde açığa çıkması esasına dayanarak yapılmıştır. Bunun için, PDA ortamında geliştirilen funguslardan alınan $3 \mathrm{~mm}$ çapında bir fungal disk, ortamdan bir cork-borer yardımı ile kesilerek bir pipet ucu ile alınmış, 1.5 $\mathrm{ml}$ hacmindeki Eppendorf tüplere yerleştirilmiştir. $\mathrm{Bu}$ tüplere $120 \mu \mathrm{l}$ hacimde $50 \mathrm{mM}$ Tris- $\mathrm{HCl}(\mathrm{pH}$ 8.8) içinde hazırlanan, $1 \%$ lik (w/v) azocasein ilave edilmiştir. Azocaseinin parçalanması için, tüpler oda sıcaklığında 1 saat inkube edilmiş, reaksiyon $300 \mu \mathrm{l}(10 \%, \mathrm{w} / \mathrm{v})$ soğuk trichloro acetik asit (TCA) ilavesi ile sonlandırımıştır. Daha sonra $15000 \mathrm{~g}$ de 10 dakika santrifüj işleminden sonra, $350 \mu$ supernatant alınarak $300 \mu \mathrm{l} 1 \mathrm{M} \mathrm{NaOH}$ ile karıştırılıp ve bir kez daha yukarıda bahsedildiği gibi santrifuj işlemi yapılmış, proteaz aktivitesi 440 $\mathrm{nm}$ dalga boyunda spektrofotometrede (Shimadzu: UV-1800) ölçülmüştür. Sonuçlar, A440 dak $^{-1} \mathrm{mg}$ protein ${ }^{-1}$ olarak ifade edilmiştir (Girard ve Michaud, 2001; Dikilitaş ve ark., 2018).

\section{Prolin ölçümü}

Prolin içeriği kısmen modifiye edilerek Bates ve ark.,(1973) yöntemine göre belirlenmiştir. Protein aşamasında elde edilen solüsyon, prolin analizi için de kullanılmıştır. Elde edilen supernatant, 2 $\mathrm{ml}$ ninhidrin(1.25 g Ninhidrin, $30 \mathrm{ml}$ Glacial asetik asit, $20 \mathrm{ml} 6 \mathrm{~mol} \mathrm{~L}^{-1}$ fosforik asit) test tüpünde $100^{\circ} \mathrm{C}^{\prime}$ de 1 saat kaynatılmıştır. Sonra buzlu ortama alınıp $5 \mathrm{ml}$ toluen eklenerek tüpler çalkalanmış (15-20 sn), 20 dakika bekletildikten sonra tüplerdeki karışımın iki tabakaya ayrılması sağlanmıştır ve $515 \mathrm{~nm}$ toluen kontrolüne karşı okutulmuştur. Standart olarak önceden hazırlanmış olan L-prolin solüsyonu kullanılmıştır. 
Malonadialdehit (MDA) analizi

Malonadialdehit analizi için modifiye edilmiş Karakaş Dikilitaş(2013); Sariam ve Saxena (2000), yöntemleri kullanılmıştır. Buna göre 3 adet fungal disk (5 mm) PDA ortamından alınıp, $2 \mathrm{ml}$ trichloro asetik asit (TCA) içinde homojenize edilmiş 12000 $g^{\prime}$ de 10dakika santrifüj edilmiştir. Elde edilen supernatant $(1 \mathrm{ml}), 4 \mathrm{ml} \% 0.5$ thiobarbutonik

$$
\operatorname{MDA}\left(\mathrm{nmolg}^{-1} \text { misel }\right)=\frac{\text { ekstrakt hacmi }(\mathrm{ml}) \times\left[\left(\mathrm{A}_{532}-A_{600)}\right) /\left(155 \mathrm{mM}^{-1} \mathrm{~cm}^{-1}\right)\right]}{\text { Ornek miktarl }(\mathrm{g})} \times 10^{3}
$$

\section{Melaninanalizi}

Melanin ekstraksiyonu ve analizi Gadd (1982)'a göre yapılmıştır. Yaklaşık 1 gram miselyum, Petri kaplarından kazınarak, $5 \mathrm{ml}$ saf su içinde 5 dakika kaynatılıp santrifüj edilmiştir (5 000 g, 5 dakika). Daha sonra miseller yıkanıp, tekrar santrifüj edildikten sonra $120^{\circ} \mathrm{C}^{\prime}$ de 20 dakika süreyle $3 \mathrm{ml}$ (1 $\mathrm{mol} \mathrm{L}^{-1}$ ) $\mathrm{NaOH}$ ile otoklav edilmiştir. Bunu takiben, alkalin pigment ekstraktının konsantre $\mathrm{HCl}$ ile asitlendirilmesi ile melanin çökertilmiştir. Çökelti damıtılmış suda üç kez yıkanıp daha ileri analiz için nemden arındırılmış koşulda bir gece boyunca $\quad 20^{\circ} \mathrm{C}$ de kurutulmuştur. Spektrofotometrik analiz için kurutulmuş pellet 1 $\mathrm{ml}\left(1 \mathrm{~mol} \mathrm{~L}^{-1}\right) \mathrm{NaOH}$ içerisinde $80^{\circ} \mathrm{C}^{\prime}$ de 2 saat süreyle çözündürülüp ardından 12,000 g'de 10 dakika santrifüj edilmiştir. Süpernatant yeni tüplere aktarılmış ve absorbans 405 nm'de ölçülmüştür.

\section{Verilerin değerlendirilmesi ve analizlerin yapılması}

Veriler tek yönlü varyans analiz yöntemi (ANOVA) kullanarak Tukey's Test Yöntemi ile analiz edilmiştir. Gruplar arasındaki farklar $\mathrm{P}<$ 0.050 den düşük olduğu zaman önemli bulunmuştur. Veriler ayrıca Ortalama \pm Standart hata $(\mathrm{SH})$ olarak ifade edilmiş, istatistik analizler SPSS veri analiz paket programı (2013 IBM Statics for Windows Version 22.0) yardımı ile yapılmıştır.

\section{Araştırma Bulguları ve Tartışma}

\section{Spor sayısı}

Fungal izolatların gelişimi, sıcaklık artışından olumsuz etkilenmiş spor üretiminde azalma asetik asit içeren $\% 20^{\prime}$ lik TCA ile $95^{\circ} \mathrm{C}^{\prime}$ de 30 dakika kaynatılmıştır. Daha sonra hızla buz banyosu yapılarak soğutulmuştur. MDA konsantrasyonu 532 ve $600 \mathrm{~nm}$ 'de spektrofotometre (Shimadzu: UV-1800) cihazında absorbans okumaları yapılarak aşağıdaki formüle göre hesaplanmıştır. Blank kontrol olarak \% 0.5 TBA kullanılmıştır. meydana gelmiştir. En yüksek spor verimi 15 ve $25^{\circ} \mathrm{C}^{\prime}$ de elde edilmiştir. Düşük sıcaklıktaki $\left(4^{\circ} \mathrm{C}\right)$ spor üretimi yüksek sıcaklıktaki $\left(30-, 35^{\circ} \mathrm{C}\right)$ spor üretiminden daha fazla bulunmuştur. Spor üretimi optimum sıcaklık koşullarından (15-, $25{ }^{\circ} \mathrm{C}$ ) uzaklaştıkça olumsuz etkilenmekle beraber yüksek sıcaklıktaki etkileri daha fazla olmuştur. Hatta fungal gelişim $35^{\circ} \mathrm{C}^{\prime}$ den sonra tamamen inhibe edilmiştir.

Fungal izolatlar karşılaştırıldığında, bütün izolatların 1 ay içinde $\left(35^{\circ} \mathrm{C}\right.$ hariç) test edilen tüm sıcaklıklarda gelişme gösterdiği tespit edilmiş, 1 aylık süre zarfında spor üretiminde artış görülmüştür. Bütün izolatlar $4-, 15^{\circ} \mathrm{C}$ arasında birim hacimde $\left(\mathrm{mm}^{3}\right)$ yüksek sporulasyon vermişlerdir $\left(2.8 \times 10^{5}-, 13.8 \times 10^{6}\right.$ spor $\left.\mathrm{ml}^{-1} \mathrm{~mm}^{-3}\right)$. Bu izolatlardan CU100SA4 izolatı $4^{\circ} \mathrm{C}^{\prime}$ de en yüksek sporulasyona ulaşan izolat $\left(13.8 \times 10^{5}\right.$ spor ml-1 $\mathrm{mm}^{-}$ $\left.{ }^{3}\right)$ olarak kaydedilmiştir (Şekil 1). Genel itibari ile izolatlar arasında en düşük sporulasyon kapasitesine sahip CU112SK239 ve CU107StH110 izolatları hem düşük $\left(4,-15^{\circ} \mathrm{C}\right)$ hemde yüksek $\left(30^{\circ} \mathrm{C}\right)$ sıcaklıklarda düşük sporulasyon vermiş olmasına rağmen enfeksiyon oluşturabilecek kapasitede spor üretiminde bulunmuşlardır. Genel olarak bütün izolatlar, $15^{\circ} \mathrm{C}$ üzerindeki sıcaklıklarda sporulasyon açısından düşük performans sergilemişler bu durum fungal etmenin serin koşullarda daha etkin olabileceğinin kriteri olarak değerlendirilmiştir.

Benzer sonuçlar Saidi ve ark. (2012),tarafından da rapor edilmiştir. YMDA (maya özü, malt özü, dextrose agar) ortamındaZ. triticisporlarının $18^{\circ} \mathrm{C}$ ve $20^{\circ} \mathrm{C}$ 'de yüksek oranda üretildiklerini belirlemişlerdir. Chungu ve ark. (2001), ise nemli 
periyot süresini uzatıp sıcaklıkları $18^{\circ} \mathrm{C}^{\prime}$ den $20^{\circ} \mathrm{C}^{\prime}$ ye çıkardıklarında elde ettikleri spor miktarını $1 \times 10^{6}$ spor $\mathrm{ml}^{-1}$ den $1 \times 10^{7}$ spor $\mathrm{ml}^{-1}$ ye çıkarmışlardır. Kültür ortamlarındaki katkı maddeleri Z. tritici'de spor üretimi üzerinde etkili bir faktördür. Kültür ortamlarının sporulasyon verimini sıcaklık, ışık ve $\mathrm{pH}$ gibi diğer faktörlerde etkilemektedir (Guo ve ark., 2008). Patojen izolatlarının sıcaklıklara farklı tepkiler verebilmesi, patojene karşı alınacak kültürel önlemler için önemlidir. Ayrıca geliştirilecek dayanıklı buğday çeşitleri, açısından yüksek sıcaklık ya da düşük sıcaklıklar patojenin enfeksiyon kabiliyeti üzerinde büyük önem arz ettiğinden, ortam sıcaklığının artmasının tek başına etkili olamayacağı, ortamda nem olduğu durumlarda spor üretiminin artarak devam edeceği rapor edilmiştir.

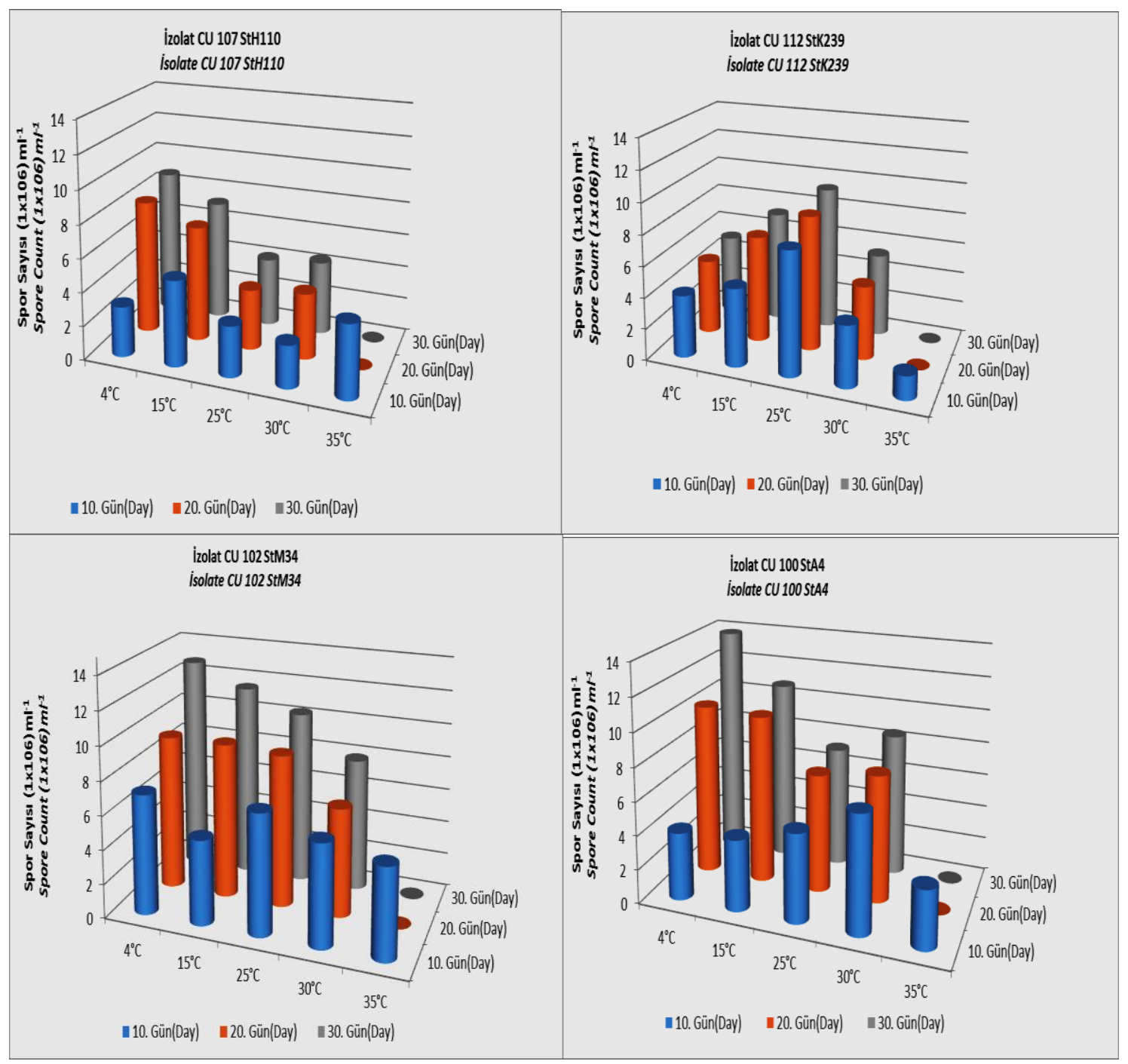

Şekil 1. Z.tiritici izolatlarının spor üretimi

Figure 1. Spor productıon of Z.tritici isolates

\section{Fungal etmenin protein içeriğinin belirlenmesi}

Z. tritici izolatlarının protein içerikleri sıcaklık koşullarına bağlı olarak yine sporulasyon aşamasında olduğu gibi değişim göstermiştir. Serin koşullarda $\left(4^{\circ} \mathrm{C}^{\prime} \mathrm{de}, 0.59-0.85 \mathrm{mg} \mathrm{g}^{-1}\right.$ yaş misel ağırlık; $15^{\circ} \mathrm{C}^{\prime}$ de $0.75-0.87 \mathrm{mg} \mathrm{g}^{-1}$ yaş misel ağırlık) Z. triticiizolatları sırası ile sporulasyon verilerinde olduğu gibi en yüksek protein sentezini gerçekleştirmişlerdir. Ancak sıcaklığın artışı ile protein sentezinde düşüş görülmüştür. Bütün izolatlar ortam sıcaklığı 20 ve $30^{\circ} \mathrm{C}^{\prime}$ ye ulaştığında protein sentezi serin koşullara göre önemli oranda düşmüş $\left(25^{\circ} \mathrm{C}^{\prime}\right.$ de $0.57-0.63 \mathrm{mg} \mathrm{g}^{-1}$ yaş misel ağırlık), sıcaklık artışının $30^{\circ} \mathrm{C}^{\prime}$ ye ulaşması ile bu değerler önemli ölçüde ( $p \leq 0.05$ ) düşmüştür (Çizelge 1 ).

Fungal patojenlerin yapısında bulunan proteinlerin stres altında savunma mekanizması ve virülenslik derecesi üzerinde etkili bir rol oynadığı bilinmektedir (Paper ve ark., 2007). Patojen fungusların proteinleri, enzim sentezi ve 
benzer metabolizma faaliyetleri için önemli olduğundan, enfeksiyon süreçlerinin başlatılması, hastalık şiddetinin belirlenmesinde ve oluşan birçok reksiyonda anahtar rol oynamaktadır (Wawra ve ark., 2013). Patojenin düşük sıcaklıklarda $\left(15^{\circ} \mathrm{C}\right.$ ve $\left.25^{\circ} \mathrm{C}\right)$ nemli periyotların uzun sürmesi durumunda yüksek ürün kayıplarına neden olduğu bildirilmiştir (Chungu ve ark., 2001). Yüksek sıcaklıklarda $\left(25^{\circ} \mathrm{C}\right.$ ve $\left.30^{\circ} \mathrm{C}\right)$ patojenin protein içeriği azalmakla beraber in vitro ortamda gelişimini sürdürdüğü görülmüştür. Kuraklık ve sıcaklığa karşı geliştirilecek dayanıklı çeşitler için patojenin bu yönünün dikkate alınması büyük önem arz etmektedir.

Çizelge 1. Farklı sıcaklıklara maruz kalan Zymoseptoria tritici patojeninin protein verileri

Table 1. Protein contens of Zymoseptoria triticipathogen exposed to different temparatures

mg Protein ( $\mathrm{g}^{-1}$ Misel ağırlığ ${ }^{-1}$ )

\begin{tabular}{lccccc}
\hline $\begin{array}{l}\text { Z.tritici İzolatları } \\
\text { Z.tritici isolates }\end{array}$ & $4 \mathrm{C}^{\circ}$ & $15 \mathrm{C}^{\circ}$ & $25 \mathrm{C}^{\circ}$ & $30 \mathrm{C}^{\circ}$ & $35 \mathrm{C}^{\circ}$ \\
\hline CU112StK239 & $0.60 \pm 001 \mathrm{c}$ & $0.83 \pm 006 \mathrm{a}$ & $0.6 \pm 0.04 \mathrm{a}$ & $0.56 \pm 0.02 \mathrm{~b}$ & 0 \\
CU102StM34 & $0.89 \pm 001 \mathrm{~b}$ & $0.87 \pm 0.06 \mathrm{a}$ & $0.57 \pm 0.04 \mathrm{a}$ & $0.53 \pm 0.02 \mathrm{~b}$ & 0 \\
CU107StH110 & $0.71 \pm 0.01 \mathrm{~b}$ & $0.75 \pm 0.06 \mathrm{a}$ & $0.59 \pm 0.04 \mathrm{a}$ & $0.55 \pm 0.02 \mathrm{~b}$ & 0 \\
CU100StA4 & $0.85 \pm 001 \mathrm{a}$ & $0.75 \pm 0.06 \mathrm{a}$ & $0.63 \pm 0.04 \mathrm{a}$ & $0.59 \pm 0.02 \mathrm{a}$ & 0
\end{tabular}

\section{Proteazaktivitesinin belirlenmesi}

Patojen funguslar enfeksiyon stratejisi olarak bitkinin hücre duvarlarını tahrip edebilen enzimler salgılamaktadır. Yalnızca canlılar tarafından sentezlenebilen protein yapısında olan enzimler, hücre içerisinde meydana gelen tepkimeleri düzenleyen biyolojik katalizörlerdir (Dikilitaş ve ark., 2018). Fungusların gelişimi ve savunma mekanizmaları üzerinde önemli bir etkiye sahiptirler (Poussereau ve ark., 2001). Bu enzimlerden bazıları, selülazlar, pektin liyaz, $\beta$ galaktosidaz ve proteaz gibi enzimlerdir. Patojen salgıladığı bu enzimler sayesinde bitki dokuları arasında gelişimini kolaylaştırır (Hegedus ve Rimmer, 2005). Proteazlar bitki-patojen etkileşiminde önemli bir konuma sahiptir. Birçok enfekteli bitki dokularında proteaz enzimleri tespit edilmiştir (Ocvirk ve ark., 2020). Proteazlar ile virülenslik arasında pozitif önemli bir ilişki olduğu ortaya konmuştur (Dikilitaş ve ark., 2018).
Bu bakımdan normal değerlerinin altında ya da üstünde elde edilen değerler fungusun savunma ve virülenslik mekanizması hakkında önemli bir yere sahiptir (Rollins, 2003; Dikilitaş ve ark., 2010).

Z. tritici izolatlarının $\left(35^{\circ} \mathrm{C}\right.$ hariç $)$ maruz bırakılan bütün sıcaklıklarda proteaz enzimini sentezlendiği görülmüştür (Çizelge 2). Genel olarak patojen fungusların proteaz seviyesi onların virülenslik durumları ve patojenisite durumları ilgili bulunmuştur (Cotton ve ark., 2002; Dikilitaş ve ark., 2018). Dolayısı ile test edilen bütün sıcaklıklarda patojenin proteaz aktivitesinin tespit edilmiş olması, patojenin izolatlarının yüksek sıcaklıklarda da virülenslik gösterebileceğini ortaya koymuştur. Bu durum ırkların sıcaklığa adaptasyon yeteneği göstererek bitkileri enfekte edebilme potansiyeline sahip olduğunu göstermektedir (Dikilitaş ve ark., 2010).

Çizelge 2. Farklı sıcaklıklara maruz bırakılan Zymoseptoria tritici izolatlarının proteaz aktivitesi

Table 2. Protease activity of Zymoseptoria tritici isolates exposed to different temperatures

\begin{tabular}{lccccc}
\hline $\begin{array}{l}\text { A440 dak } \text { mg protein }^{-1} \\
\text { Z.tritici Izolatları }\end{array}$ & \multicolumn{1}{l}{${ }^{\circ} \mathrm{C}$} & $15^{\circ} \mathrm{C}$ & $25^{\circ} \mathrm{C}$ & $30^{\circ} \mathrm{C}$ & $35^{\circ} \mathrm{C}$ \\
Z.tritici isolates & & & & & \\
\hline CU112StK239 & $0.13 \pm 0.02 \mathrm{a}$ & $0.15 \pm 0.02 \mathrm{a}$ & $0.11 \pm 0.02 \mathrm{a}$ & $0.12 \pm 0.02 \mathrm{a}$ & 0 \\
CU102StM34 & $0.15 \pm 0.02 \mathrm{a}$ & $0.12 \pm 0.03 \mathrm{a}$ & $0.12 \pm 0.02 \mathrm{a}$ & $0.14 \pm 0.03 \mathrm{a}$ & 0 \\
CU107StH110 & $0.12 \pm 0.02 \mathrm{a}$ & $0.11 \pm 0.03 \mathrm{a}$ & $0.10 \pm 0.03 \mathrm{a}$ & $0.14 \pm 0.03 \mathrm{a}$ & 0 \\
CU100StA4 & $0.12 \pm 0.02 \mathrm{a}$ & $0.15 \pm 0.03 \mathrm{a}$ & $0.14 \pm 0.03 \mathrm{a}$ & $0.15 \pm 0.02 \mathrm{a}$ & 0 \\
\hline
\end{tabular}




\section{Prolindeğerlerinin ölçümü}

Fungal izolatların virülenslik derecesini tespit etmek için kullanılan proteaz aktivitesi yanında, etmenlerin stres durumunu belirlemek için prolin ve melonadialdehid ölçümleri de yapılmıştır.Bir amino asit olan prolin, fungusun etkisinde kaldığı sıcaklık faktörüne karşı doğrudan belirleyici olmasa bile stresin seviyesi hakkında önemli ipuçları vermektedir (Karakaş ve Dikilitaş, 2013). Z. tritici izolatları genel itibari ile $30^{\circ} \mathrm{C}$ 'de diğer sıcaklık değerlerine göre yüksek prolin sentezlemişler, izolatlar arasında önemli fark tespit edilmemiştir(Çizelge 3). Fungal izolatların $30^{\circ} \mathrm{C}^{\prime}$ ye kadar herhangi bir stres amino asidi sentezlemeden protein ve enzim sentezini gerçekleştirdiği tespit edilmiştir.

Serbest bir amino asit olan prolin, stress koşullarında NAD/NADH oranının düzenlenmesini sağladığından fungal patojenler ozmotik dengeyi ve $N A D / N A D H$ oranını sağlayabilmek için daha fazla prolin biriktirirler (Kishor ve ark., 2005; Zhu ve ark., 2010). Prolin osmotik ayarlamalar sağlayarak hücresel zarı sıcaklık stresine karşı koruyabilir. Hücresel asitliği azaltıp düşük sıcaklıkların verdiği hasarı azaltabilir (Sharma ve Dietz, 2006).

Çizelge 3. Farklı sıcaklıklara maruz kalan Zymoseptoria triticipatojeninin prolin değerleri

Table 3. Proline values of Zymoseptoria triticipathogen exposed to different temperatures $\mu \mathrm{mol} \mathrm{g}^{-1}$ yaş misel ağırlığı

\begin{tabular}{lccccc}
\hline Z. tritici & $4^{\circ} \mathrm{C}$ & $15^{\circ} \mathrm{C}$ & $25^{\circ} \mathrm{C}$ & $30^{\circ} \mathrm{C}$ & $35^{\circ} \mathrm{C}$ \\
\hline CU112StK239 & $5.40 \pm 0.02 \mathrm{a}$ & $5.58 \pm 0.03 \mathrm{a}$ & $5.22 \pm 0.04 \mathrm{a}$ & $7.74 \pm 0.03 \mathrm{a}$ & 0 \\
CU102StM34 & $7.02 \pm 0.03 \mathrm{a}$ & $5.04 \pm 0.02 \mathrm{a}$ & $5.40 \pm 0.03 \mathrm{a}$ & $7.56 \pm 0.04 \mathrm{a}$ & 0 \\
CU107StH110 & $6.5 \pm 0.04 \mathrm{a}$ & $4.68 \pm 0.03 \mathrm{a}$ & $5.40 \pm 0.02 \mathrm{a}$ & $8.86 \pm 0.03 \mathrm{a}$ & 0 \\
CU100StA4 & $5.04 \pm 0.04 \mathrm{a}$ & $4.95 \pm 0.03 \mathrm{a}$ & $4.50 \pm 0.02 \mathrm{a}$ & $7.66 \pm 0.03 \mathrm{a}$ & 0 \\
\hline
\end{tabular}

Malonadialdehit (MDA) değerlerinin ölçümü

Z. tritici izolatları MDA değerlerine yine prolin verilerinde olduğu gibi en yüksek $30^{\circ} \mathrm{C}^{\prime}$ de ulaşmıştır. Fungal izolatlar, diğer sıcaklıklarda MDA açısından istatistiksel olarak önemli farklılıklar göstermemiştir. Göreceli olarak 15$25^{\circ} \mathrm{C}$ arasında MDA değerleri diğer sıcaklıklara göre düşük bulunmuş, genel olarak $30^{\circ} \mathrm{C}$ 'de stres metaboliti sentezlemişler, ancak izolatlar arasında önemli fark tespit edilmemiştir.

Lipidperoksidasyonu sonucunda oluşan MDA, yağların bileşimlerindeki doymamış moleküllerin oksijenle yükseltgenmesi ile oluşan aldehit, keton, hidroksi asitler, keto asitler, alkoller gibi nihai bir üründür (Mittova ve ark., 2004). Lipid peroksidasyonu sıcaklık, ışık, nem gibi faktörler tarafından tetiklenebildiği gibi serbest radikaller de bu süreci başlatabilir (Thakur ve Sarhma, 2005). Bu faktörlerin etkisinin artması daha fazla MDA sentezlenmesine neden olur (Yakıt ve Tuna, 2006; ShamsPeykani ve Sephr,2018). Dolayısıyla MDA seviyesi genellikle bir stres göstergesi olarak kabul edilmektedir. MDA seviyesinin sıcaklık stresinin etkisini tolere edebilmek ve ozmotik dengeyi sağlamak için üretildiği düşünülmektedir (Çizelge 4).

Çizelge 4. Farklı sıcaklıklara maruz bırakılan Zymoseptotia tritici patojeninin MDA değerleri Table 4. MDA values of Zymoseptotia triticipathogen exposed to different temperatures $\mathrm{nmol} \mathrm{g}^{-1}$

\begin{tabular}{lccccc}
\hline Z.tritici & $4{ }^{\circ} \mathrm{C}$ & $15{ }^{\circ} \mathrm{C}$ & $25^{\circ} \mathrm{C}$ & $30{ }^{\circ} \mathrm{C}$ & $35^{\circ} \mathrm{C}$ \\
\hline CU112StK239 & $6.28 \pm 0.04 \mathrm{~b}$ & $3.61 \pm 0.04 \mathrm{~b}$ & $1.68 \pm 0.01 \mathrm{a}$ & $11.14 \pm 0.01 \mathrm{~b}$ & 0 \\
CU102StM34 & $10.80 \pm 0.03 \mathrm{a}$ & $2.37 \pm 0.01 \mathrm{a}$ & $1.85 \pm 0.02 \mathrm{a}$ & $12.25 \pm 0.01 \mathrm{~b}$ & 0 \\
CU107StH110 & $5.72 \pm 0.03 \mathrm{~b}$ & $2.77 \pm 0.02 \mathrm{a}$ & $1.44 \pm 0.03 \mathrm{a}$ & $13.40 \pm 0.02 \mathrm{~b}$ & 0 \\
CU100StA4 & $10.52 \pm 0.02 \mathrm{a}$ & $1.56 \pm 0.02 \mathrm{a}$ & $2.02 \pm 0.02 \mathrm{a}$ & $8.74 \pm 0.03 \mathrm{a}$ & 0 \\
\hline
\end{tabular}

\section{Zymoseptotia tritici'nin melanin değerleri}

Birçok organizmada önemli koruyucu roller üstlenen melanin normal ve stres koşullarında fungal etmenin hücre duvarında sentezlenen bir pigment olarak bilinmesine karşın son yıllarda strese karşı oluşturulan dayanıklılık, virülenslik ve 
enerji nakli gibi konular ile de ilişkilendirilmiştir(Zhu ve ark., 2010). Birçok fungus, fenolik bileşiklerin oksidatif polimerizasyonu ile oluşan koyu kahverengi ve siyah pigmentlerden oluşan melaninleriüretir(Heidrich ve ark., 2019). Melaninler bir örtü görevi görerek organizmayı sıcak-soğuk ve kuraklık stresi gibi çevresel faktörlere karşı korumada rol oynayabilen önemli bir karbonhidrattır(Pacelli ve ark., 2017). Ayrıca serbest radikaller, UV ve solar radyasyon gibi fiziksel etkilere karşı koruyucu bir görev üstlendiği bilinmektedir (Geng ve ark., 2008).

Kubo ve Furusawa (1991) bitkilerde antraknoza neden olan Colletotrichum türlerinde appressorium oluşumu ve penetrasyonu üzerine yaptıkları çalışmada aprressorial melanin sentezleyen ırkların daha dayanıklı olduğunu ve peneterasyon oluşturabildiğini bildirmişlerdir. Aynı araştırmacılar C. lagenarium'un albino mutantlarıyla yaptıkları çalışmada melanin içermeyen appressoryumun konukçu bitkiye nüfuz edemediğini bildirmişlerdir.

Howard ve Valent (1996) pirinç bitkisinde hastalığa neden olan Magnaporthe grisea'nın bitkiye penetrasyonu ile ilgili yaptıkları çalışmada appressoryumun aseksüel sporun bir çimlenme tüpünden tek bir hücre olarak oluştuğunu konukçu bitkiye teması sağlayan uç kısmı hariç geriye kalan hiflerin tamamen melanize bir yapıda olduğunu bildirmişlerdir. Tsuji ve ark. (2003), patojenik fungusların sentezlediği melaninin konukçu dokusunu istila etmek için gerekli olan turgor basıncın oluşmasına katkıda bulunduğunu ifade etmişlerdir.

Patojenin yüksek sıcaklıklarda melanin sentezleyerek, sıcaklık değişimlerine karşı tolerans geliştirerek ve hatta bu koşullara adaptasyon sağlayarak virülenslik şiddetini koruyabileceği görülmüştür. Patojenin çok daha yüksek sıcaklıklarda uygun nem koşullarında melanin sentezleyebilme potansiyeli abiyotik stres altında bulunan bitkiler için potansiyel tehlike oluşturacağı ortaya konmuştur.

Çizelge 5.Zymoseptoria tritici Patojeninin melanin değerleri

Table 5. Melanin values of Zymoseptoria tritici pathogen

$\triangle$ Absorbans

Absorbance

\begin{tabular}{lccccc}
\hline Z.tritici & $4{ }^{\circ} \mathrm{C}$ & $15^{\circ} \mathrm{C}$ & $25^{\circ} \mathrm{C}$ & $30^{\circ} \mathrm{C}$ & $35^{\circ} \mathrm{C}$ \\
\hline CU112StK239 & $0.382 \pm 0.06$ & $0.354 \pm 0.08$ & $0.345 \pm 0.01$ & $0.441 \pm 0.09$ & 0 \\
CU102StM34 & $0.502 \pm 0.06$ & $0.462 \pm 0.08$ & $0.334 \pm 0.01$ & $0.592 \pm 0.09$ & 0 \\
CU107StH110 & $0.480 \pm 0.06$ & $0.403 \pm 0.08$ & $0.548 \pm 0.01$ & $0.598 \pm 0.09$ & 0 \\
CU100StA4 & $0.392 \pm 0.06$ & $0.265 \pm 0.08$ & $0.331 \pm 0.01$ & $0.453 \pm 0.09$ & 0
\end{tabular}

\section{Sonuçlar ve Öneriler}

izolatların prolin miktarlarında artış meydana gelmiştir. Sıcaklıkların yükselmesi patojenin protein içeriğinde azalmaya neden olmuştur.

Z. tiritici izolatlarından hiç biri $35^{\circ} \mathrm{C}^{\prime} \mathrm{de}$ gelişememiş olup inkubasyonun 10 . gününden itibaren gelişmeleri tamamen durmuştur. Denemelerde kullanılan sıcaklık değerleri diğer araştırmacıların verileri ile paralellik göstermektedir. Ancak, fungal izolatlar $35^{\circ} \mathrm{C}^{\prime}$ den sonra yeniden oda sıcaklığına $\left(20-25^{\circ} \mathrm{C}\right)$ alındığında miselyal gelişme göstermeyen fungal izolatlar tekrar gelişmeye başlamıştır. Görsele bağlı bir çalışma olduğu için rakamsal bir veri verilmemiştir. Patojenin, optimum sıcaklık değerlerinden $\left(25^{\circ} \mathrm{C}\right)$ uzaklaştıkça söz konusu
Fungus en yüksek proteiniçeriğine $15^{\circ} \mathrm{C}^{\prime} \mathrm{de}$ ulaşmıştır. En düşük protein miktarı ise $30^{\circ} \mathrm{C}^{\prime}$ de sentezlenmiştir. Buna karşın prolin miktarı optimum koşullardan uzaklaştıkça artmıştır $\left(4^{\circ} \mathrm{C}^{\prime}\right.$ de, $7.02 \mathrm{mgg}^{-1}$ yaş misel ağırık; $30^{\circ} \mathrm{C}, 8.86 \mathrm{mgg}^{-}$ ${ }^{1}$ yaş misel ağırlık ). Bu durum fungal etmenin proteinlerinin parçalanarak proline dönüşmesi sonucu oluşmuştur. Buna karşın prolin seviyesinin artışına katkıda bulunduğunu da göstermiş sentezlenen prolinin yanında proteinlerin parçalanmasından dolayı açığa çıkan prolinin de devreye girdiği görülmüştür. Fungus en yüksek 
MDA değerine $30^{\circ} \mathrm{C}$ ulaşmış, daha sonraki en yüksek değere $4^{\circ} \mathrm{C}^{\prime}$ de ulaşmıştır. En düşük MDA değeri ise $25^{\circ} \mathrm{C}^{\prime}$ deelde edilmiştir. Patojenin gelişimi için uygun olan sıcaklıklarda MDA düşük çıkarken sıcaklık değerlerinin optimal değerlerden uzaklaşması ile MDA değerlerinde yükselme görülmüştür.

Patojenin proteaz miktarı sıcaklık değişimlerinden genel anlamda etkilenmiş, ortamın sıcaklığı arttıkça proteaz seviyesi de artmış fakat $35^{\circ} \mathrm{C}^{\prime}$ de tamamen durmuştur. Patojenlerden salgılanan proteaz miktarı in vitro koşullarda ortam içeriğine $\mathrm{pH}$ ve sıcaklık değerlerine göre değişiklik göstermektedir (Zhan ve ark., 2013).

Yine melanin açısından bakıldığında en yüksek melanin sentezi $30^{\circ} \mathrm{C}^{\prime}$ de oluşmuştur. Düşük melanin sentezi $15^{\circ} \mathrm{C}^{\prime}$ de gerçekleştirilmiştir. Fungus kendisi için uygun sıcaklık değerlerinden uzaklaştıkça oluşan sıcaklık stresinden korunmak için yapısındaki melanin miktarını arttırma yoluna giderek stresi tolere edebildiği değerlendirilmiştir.

Elde edilen bulgular sunucunda, Z. tritici'nin farklı sıcaklık değerlerine gösterdiği tepkiler biyokimyasal olarak belirlenmiş, moleküler olarak aynı olan özellikleri sentezleyen izolatların biyokimyasal davranışlarında farklılık elde edilmesi bu izolatların bulunduklarıfarklı iklim koşullarına adaptasyon geliştirebildiklerini ortaya koymuştur. Stres koşullarında patojenin göstereceği biyokimyasal davranışlar belirlendiğinde, bu patojene karşı daha etkili koruma metotlarının geliştirilmesi mümkün olacaktır. Dolayısı ile küresel ısınmadan dolayı kısa süreli sıcaklık dalgalanması bu tip fungal etmenleri kısa süreli olarak inhibe etmesi beklense de sıcaklığın düşmesi ile yeniden enfeksiyon yapma kapasitesine ulaşabileceği değerlendirilmiştir.

Z. tirici izolatlarının yüksek sıcaklıklarda da proteaz enzim sentezleyebilmesi veya izolatlar arasında enzimsel açıdan farklılık bulunması, patojen izolatlarının faklı adaptasyon kabiliyetlerine de sahip olabileceği anlamına gelmektedir. Dolayısı ile ilerleyen zaman içinde aynı bölgelerden tekrar yapraktan izole edilerek izolatların enzimal performanslarının tekrar teyit edilmeleri ile patojen izolatlarının adaptasyon kabiliyeti de belirlenmiş olacaktır.

\section{Ekler}

Bu makale yazarın aynı adlı tez çalışmasından türetilmiştir.

Çıkar çatışması:“Makale yazarları, aralarında herhangi bir çıkar çatışması olmadığını beyan eder".

Yazar Katkısı: Nevzat KILINÇ, çalışmayı tasarlayarak denemeyi kurmuştur, Nevzat KILINÇ ve Murat DikiLiTAŞ çalışmayı yürütmüş, verileri analiz etmiştir.Mukaddes KAYIM ve GÜLSÜM ÜNAL izolatların elde edilmesi ve hastalık etmeninin teşhisini yapmıştır.

\section{Kaynaklar}

Bates, L.S., Waldren, R.P. ve Teare, I.D., (1973). Rapid determination of free proline for water stress studies. Plant Soil, 39:205-207.

Bremer, H., Ismen, H., Karel, G., Ozkan, H. ve Özkan, M., (1948). Contributions to the knowledge of the parasitic fungi of Turkey Part III. Journal Article Rev. Fac. Sci. Univ. Istanbul, 13(1), 1-53.

Bora, T. ve Karaca, I., (1970). Bitki hastalıkları sürveyi. Kültür bitkilerinde hastalığın ve zararın ölçülmesi. Ege Üniversitesi, Ziraat Fakültesi Yardımcı Ders Kitabı, Yayın No: 167, Ege Üniversitesi Matbaası, Bornova. 43s.

Chungu, C., Gilbert, J. and Townley, S.F., (2001). Septoria tritici blotch development as affected by temperature, duration of leaf wetness, inoculum concentration, and host. Plant Dis, (85), 430-435.

Cotton, P., Rascle, C. and Fevre, M., (2002). Characterization of PG2, an early endo PG produced by Sclerotinia sclerotiorum, expressed in yeast. FEMS Microbiology Letters, 213(2), 239-244.

Dikilitaş, M., Oğuz, A.Ç. ve Karakaya, A., (2018). Extracellular protease activity and glucose production in isolates of net blotch pathogens differing in virülence. Zemdirbysite-Agriculture, 105(1), 89-94.

Dikilitaş, M. ve Karakaş, S., (2010). Salt as potential environmental pollutants, their types, effects on plants, and approaches for their phytoremediation. plant adaptation and phytoremediation (Edited By M. Ashraf, M. Ozturk, M.S.A. Ahmad). Springer Dordrecht, Heidelberg, London, New York, 357-383.

Eğerci, Y., Öztürk, M.Ö. ve Hekimhan, H., (2020). Ege bölgesi'nde buğdayda septorya yaprak lekesi hastalığı (zymoseptoria tritici)'nın yaygınlığının belirlenmesi ve moleküler tanılanması. The Turkish Journal of Phytopathology, 49 vol.,issue (3), 63-67. 
Essahibi, A., Benhiba, L. and Babram, M.A., (2018). Influence of arbuscular mycorrhizal fungi on the functional mechanisms associated with drought tolerance in carob (Ceratonia siliqua L.). Trees 32,87-97. https://doi.org/10.1007/s00468-017-1613-8.

Gadd, G.M., (1982). Effect of media composition and light on colony differentation and melanin synthesis in Microdochium bollei. Trans. Br. Mycol. Soc., (78), 115-122.

Geng, J., Yu, S.B., Wan, X., Wang, X.J., Shen, P., Zhou, P. and Chen, X.D., (2008). Protective action of bacterial melanin against DNA damage in full UV spectrums by a sensitive plasmid-based noncellular system. J Biochem Biophys Methods, 70(6), 1151-1155.

Girard, C. and Michaud, D., (2001). Validation of methyl malondialdehyde as internal standard for malondialdehyde detection by capillary electrophoresis. Analytical Biochemistry, 308, 388391.

Goodwin, S.B., Barek, M.S.B., Dhillon, B., Wittenberg, A.H., Crane, C.F. and Hane, J.K., (2011). Finished genome of the fungal wheat pathogen Mycosphaerella graminicola reveals dispen some structure, chromosome plasticity, and stealth pathogenesis. Plos Genetics, (7), 1-17.

GUO, J.R. and Verreet, J.A., (2008). Formation and Germination of Septoria tritici secondary conidia as affected by environmental factors. Journal of Phyto pathology, (156), 635-637.

Heidrich, D., Corbellini, V.A., Mendes, S.D.C., Fernandes, E.K., Lazzarotto, L., Ribeiro, A.C., Zanette, R,A. and Scroferneker, M.L., (2019). Melanin: quantification and protection agains toxidative stress in chromo blastomycosis agents. MedMycol, (57), 260-263.

Hegedus, D.D. and Rimmer, S.R., (2005). Sclerotinia sclerotiorum: When "to be or not to be" a pathogen? Microbiology Letters, (251), 177-184.

Howard, R.J. and Valent, B., (1996). Breaking and entering: host penetration by the fungal rice blast pathogen Magnaporthe grisea. Annu Rev Microbiol, (50), 491512.

İren, S., (1962). Tarla bitkileri hastalıkları. Ayyıldız Matbaası, Ankara, 3-94s.

Karakaş Dikilitaş, S., (2013). Farklı tuz seviyelerindeki topraklarda yetiştirilen domatesin gelişimi ve bazı fizyolojik özellikleri ile toprak iyileştirilmesi üzerine arkadaş bitkilerin etkileri. Harran Üniversitesi, Fen Bilimleri Enstitüsü, Doktora Tezi, Şanlıurfa, 315s.

Kirk, P.M., Cannon, P.F., David, J.C. and Stalpers, J.A., (2001). Ainsworth and Bisby's dictionary of the fungi. CABI Publishing, Cambridge.

Kishor, K., Sangam, S., Amrutha, R.N., Sri Laxmi, P. and Naidu, K.R., (2005). Regulation of proline biosynthesis, degradation, uptake and transport in higher plants. Current Science, 88(3), 424-438.

Kubo, Y. and Furusawa, I., (1991). Melanin Biosynthesis. The fungal spore and disease initiation in plants and animals. Springer, Boston. 540pp.

Kurt, Ş., (2016). Bitki fungal hastalıkları. Akademisyen Kitap Evi, İstanbul, 214s.

Kurt, Ş. ve Tok, F.M., (2006). Influence of inokulum concentration, leaf age, temperature and duration on leaf wetnes on Septoria Blight of parsley. Crop
Protection, 25, 556-561.

Mittova, V., Guy, M., Tal, M. Ve Volokita, M., (2004). Salinity up-regulates the antioxidative system in root mitochondria and peroxisomes of wild salt-tolerant tomato species Lycopersicon pennellii. Journal of Experimental Botany, 55(399), 1105-1113.

Ocvirk ,D., Špoljarević,M., Kristić, M.. Hancock,J.T., Teklić, T. and Lisjak, M., (2020). The effects of seed priming with sodium hydrosulphide on drought tolerance of sunflower (Helianthus annuus L.) in germination and early growth. Ministry of Science and Technology, Croatia, Grant/Award Number: 079-0790494-0559.

Pacelli, C., Bryan, R.A., Onofri, S., Selbmann, L., Shuryak, I. and Dadachova, E., (2017). Melanin is effective in protecting fast and slow growing fungi from various types of ionizing radiation. Environment Microbiology, 19, 1612-1624.

Paper, J.M., Scott C.J.S., Adhikari, N.D., Cuomo, C.A. and Walton, J.D., (2007). Comparative proteomics of extracellular proteins in vitro and in planta from the pathogenic fungus Fusarium graminearum. Proteomics, 7(17), 3171-3183.

Poussereau, N., Creton, S., Grand, G.B., Rascle C. and Fevre, M., (2001). Regulation of acp1, encoding a nonaspartyl acid protease expressed during pathogenesis of Sclerotinia sclerotiorum. Microbiology, 147, 717-726.

Rollins, J.A., (2003). The Sclerotinia sclerotiorum pac1 Gene Is required for sclerotial development and virulence. The American Phytopathological Society, 16(9), 785795.

Saidi, A., Eslahi, M.R. and Safaie, N., (2012). Efficiency Of Septoria tritici sporulation on different culture media. Trakia Journal of Sciences, 10(3), 15-18.

Sairam, R. K. and Saxena, D. C., (2000). Oxidative stress and antioxidants in wheat genotypes: possible mechanism of water stress tolerance. Journal of Agronomy and CropScience, 184(1), 55-61.

Shams Peykani, L. and Sepehr, M.F., (2018). Effect of chitosan on antioxidant enzyme activity, proline, and malondialdehyde content in Triticuma estivum L. and Zeamaize L. under salt stres condition. Iranian Journal of PlantPhysiology, 9 (1), 2661- 2670.

Sharma, S.S. and Dietz, K.J., (2006). The significance of amino acids and amino acid-derived molecules in plant responses and adaptation to heavy metal stres. Journal of Experimental Botany, 57(4), 711-726.

Sidhu, Y.S., Chaudhari, Y.K., Usher, J., Cairns, T.C., Csukai, M. and Haynes, K., (2015). A suite of gateway compatible ternary expression vectors for functional analysis in Zymoseptoria tritici. Fungal Genet. Biol., 79, 180-185.

Thakur, M. and Sharma, A.D., (2005). Salt-stress Induced proline accumulation in germinating embryos: evidence suggesting a role of proline in seen germination. Journal of Arid Environments, 62, 517523.

Torriani, S.F.F., Brunner, P.C., Mcdonald, B.A. and Sierotzki, H., (2009). Qo Iresistance emergedin dependently at least 4 times in European populations of Mycosphaerella graminicola. PestManage. Sci., 65, 155-162.

Tsuji, W., Mek, A., Inanaga, S. and Sugimoto, Y., (2003). 
Growth and gas exchange of three sorghum cultivars under drought stress. Biomedical and Life Sciences, 46(4), 583-587.

Unal, G., Kayim, M., Ay, T. ve Yones, A.M., (2017). Evaluation of disease intensity and molecular identification of Zymoseptoria tritici causing Septoria leaf blotch on wheat in the Eastern Mediterranean Region of Turkey. Turk. Agric. For., 41, 405-413.

Wawra S., Djamei, A., Albert I, N.U., Rnberger, T. and Kahmann, R., (2013). In vitro translocation experiments with RxLR-reporter fusion proteins of Avr1b from Phytophthora sojae and AVR3a from Phytophthora infestans fail to demonstrate specific autonomous uptake in plant and animal cells. Mol Plant Microbe Interact, 26, 528-536.

Yakit, S. Ve Tuna, A.L., (2006). Tuz stresi altındaki mısır bitkisinde (Zea mays L.) stres parametreleri üzerine
Ca, Mg ve K'un etkileri. Akdeniz Üniversitesi, Ziraat Fakültesi Dergisi, 19(1), 59-67.

Mustafa, Z., (2020). Distribution of Septoria tritici blotch disease agent Zymoseptoria tritici mating type idiomorphs in Turkey. Bitki Koruma bülteni, 60 (3), 33-38.

Zhan, F., Xie, Y., Zhu, W., Sun, D., Mcdonald, B.A. and Zhan, J., (2016). Linear correlation analysis of Zymoseptoria tritici aggressiveness with in vitro growth rate. Phytopathology, 106, 1255-1261.

Zhan, J. and Mcdonald, B. A., (2013). Experimental measures of pathogen competition and relative fitness. Annu. Rev. Phytopathology, 51, 131-153.

Zhu, X.C., Song, F.B. and Xu, H.W., (2010). Arbuscular mycorrhizae improves low temperature stress in maize via alterations in host water status and photosynthesis. PlantandSoil, 331(1), 129-137. 